\title{
Wojenne i powojenne dzieje banków, ich skarbców i dokumentacji - przykład Komunalnej Kasy Oszczędności powiatu poznańskiego
}

Za przysłowiowe wręcz uchodzi określenie „pewne jak w banku”, co jest pochodną starań tych instytucji na rzecz jak najlepszego zabezpieczenia wszelkich zasobów im powierzonych. Ochrona ich, szczególnie w okresie wojen lub innych niepokojów, wymaga jednak znacznego wysiłku. W trakcie działań wojennych banki, podobnie jak i inne obiekty, nawet te niewykorzystywane do celów wojskowych, podatne są na zniszczenia (np. w trakcie bombardowań). Taki sam los spotka często ich dokumentację. Zapobiec temu miało m.in. jej ukrycie oraz ewakuacja. Znane są przypadki takich działań podejmowanych przez władze banków centralnych ${ }^{1}$. Ratowano również zasoby banków lokalnych, które ewakuowały tę zawartość swoich skarbców, która ostała się po najczęściej panicznych reakcjach klientów. Przykładem takiego rozwiązania może być wywóz części zawartości bankowej registratury i archiwum na wschód przez personel Komunalnej Kasy Oszczędności miasta Poznania oraz ich ukrycie 13-16 września 1939 r. Według relacji złożonej przez jednego z pracowników tego banku, jego najważniejsze dokumenty zostały ewakuowane $\mathrm{z}$ Poznania $\mathrm{w}$ jutowych workach i $\mathrm{w}$ takim stanie zostały ukryte w jednej ze wsi zabużańskich, gdzie udało się dotrzeć konwojowi ewakuacyjnemu składającemu się z pracowników $\mathrm{KKO}^{2}$.

${ }^{1}$ Do rangi prawdziwej epopei urosła np. sprawa ewakuacji polskiego złota będącego w posiadaniu Banku Polskiego. Zob. W. Rojek, Odyseja skarbu Rzeczypospolitej. Losy złota Banku Polskiego 1939-1950, Kraków 2000.

${ }^{2}$ Według relacji przekazanej do poznańskiego Archiwum Państwowego, dokumentacja KKO miasta Poznania została „zabezpieczona” w budynku szkoły we wsi Wysokie w pobliżu Brześcia nad Bugiem poprzez zakopanie jej pod glinianą polepą jednego z pomieszczeń 
Podczas bezpośrednich walk banki, ich siedziby, dokumentacja oraz zgromadzone środki były niejednokrotnie obiektem dużego zainteresowania walczących stron, a szczególnie niektórych żołnierzy. Skarbce banków bowiem zawsze rozpalają wyobraźnię amatorów szybkiego i łatwego wzbogacenia się. Miało to miejsce także podczas największego konfliktu zbrojnego, jaki ogarnął naszą planetę, tj. II wojny światowej.

Bardzo podobny opis przypadków, jakie spotykają banki w trakcie działań wojennych, zawiera sprawozdanie pierwszego powojennego dyrektora KKO powiatu poznańskiego, które zostało zamieszczone poniżej. Dokument przedstawia opis zachowań żołnierzy liczących na zdobycie zawartości skarbca jednego $z$ banków poznańskich działających w okresie okupacji. Jest to jedno z nielicznych źródeł powstałych tuż po zakończeniu działań wojennych, pokazujących, jak traktowane były banki podczas działań wojennych, oraz opisujące wznowienie działalności tuż po ich zakończeniu. Sprawozdanie z 22 marca 1945 r., przygotowane przez dyrektora KKO powiatu poznańskiego, dotyczy newralgicznych kwestii odbudowy i funkcjonowania tej placówki, tj.: zabezpieczenia majątku b. niemieckiej Kasy Oszczędności, która zainstalowana została $\mathrm{w}$ gmachu przedwojennego Komunalnego Banku Kredytowego w Poznaniu, wymiany marek niemieckich na złote polskie ${ }^{3}$ oraz ustroju Komunalnej Kasy Oszczędności w Poznaniu. Znaleźć tutaj też można informacje o organizacji KKO powiatu poznańskiego w okresie przedwojennym oraz jej majątku i przepisach normujących działanie. Ukazano również los banku i jego pracowników w okresie okupacji niemieckiej oraz zarysowano organizację systemu banków komunalnych w okresie okupacji na terenie Warthegau.

Dokument zawierający informacje o potraktowaniu skarbca bankowego przez poszukujących zdobyczy wojennej żołnierzy Armii Czerwonej jest zarazem dowodem, jak nieodległe od rzeczywistości mogą być niejednokrotnie scenariusze filmowe ${ }^{4}$. Jest prawdopodobne, że w taki sam sposób, jak skar-

szkolnych. Worki z dokumentacją zostały przysypane warstwą piasku. Zob. APP, akta własne Rewindykacje, windykacje i ekstradycja - informacja J. Gugało z 29 stycznia 1996 r.

${ }^{3}$ Z dokumentu wynika np., że każda z osób dokonujących wymiany pieniędzy dysponowała kwotą ponad tysiąc reichsmarek. Biorąc pod uwagę wynagrodzenia z okresu okupacji polskich mieszkańców Poznania, pozwalające na zaledwie minimum egzystencji, wskazywać to może albo na realizację wymiany przez jednego klienta banku wspólnie dla wielu osób lub na wymianę środków, które były łupem wojennym, a transakcję przeprowadzały na zlecenie posiadaczy podstawione osoby. Zob. też K. Stryjkowski, Poznań '45. Ostatni rok wojny i pierwszy rok odbudowy, Poznań 2013, s. 325.

${ }^{4}$ Przykład taki przedstawiono chociażby w kultowym obrazie filmowym Złoto dla zuchwatych z 1970 r. w reż. Briana G. Huttona. W filmie wzięły udział gwiazdy światowego kina, a nie tylko kinomanom znane są chociażby takie nazwiska, jak: Telly Savalas, Clint Eastwood czy Donald Sutherland. Grani przez nich w filmie żołnierze amerykańscy, licząc na bogate łupy, w bezceremonialny sposób chcą obejść się ze skarbcem jednego z francuskich prowincjonal- 
biec poznańskiego banku, zostały potraktowane placówki bankowe w innych miastach z terenów, skąd wypierane były oddziały Wehrmachtu. Udziałem terenów należących nawet do krajów uznawanych za sojusznicze były rabunki, które dotykały nie tylko gmachów instytucji państwowych i publicznych, lecz również mienia prywatnego, np. opuszczonych domostw i mieszkań. Dotyczyło to także opuszczonych terenów należących przed wybuchem wojny do Rzeszy Niemieckiej. Śladów takiej praktyki można zapewne poszukiwać chociażby w relacjach ówczesnej ludności niemieckiej. Wiadomym jest także, że wiele z zasobów pozyskanych w ten właśnie sposób posłużyło później wzmocnieniu potencjału wojskowego zwycięskich państw ${ }^{5}$.

Zamieszczony poniżej dokument posiada wiele walorów. W pierwszym rzędzie oddaje atmosferę, w jakiej przyszło odbudowywać po wojennej zawierusze instytucje bankowe $w$ Polsce. Uwagę zwraca np. fakt bardzo szybkiego stawienia się do pracy wszystkich zdolnych do tego przedwojennych pracowników bankowych. Innym zagadnieniem wymagającym zaakcentowania jest zwrócenie uwagi $\mathrm{w}$ dokumencie na kwestie wizerunkowe i reklamę banku, którego pracownikiem był Franciszek Wojciechowski. Bardzo szybkie podjęcie działalności oraz prowadzenie wymiany marki niemieckiej na złotego mogło, jego zdaniem, wpłynąć na pozyskanie przez KKO powiatu poznańskiego nowych klientów - mieszkańców Poznania. Autorem prezentowanego dokumentu jest Franciszek Wojciechowski ${ }^{6}$, a jego adresatem starosta powiatu poznańskiego. $\mathrm{W}$ dokumencie zachowano pisownię oryginalną.

nych banków. Jest on wykorzystywany do czasowego przechowywania złota konwojowanego przez żołnierzy niemieckich, którzy otrzymali rozkaz jego przetransportowania do Niemiec. Przy okazji, by dostać się do miasteczka, w którym znajduje się bank, „zuchwali” przełamują front i zapoczątkowują wielką ofensywę wojsk amerykańskich na froncie zachodnim II wojny światowej. W finałowej scenie filmu dochodzi nawet do zawieszenia broni pomiędzy walczącymi stronami oraz współpracy, która doprowadzić ma do podziału przewożonego i chronionego przez Niemców skarbu.

${ }^{5}$ O wykorzystaniu zasobów archiwów niemieckich oraz dokumentacji wytworzonej w okresie III Rzeszy zob. K. Stryjkowski, Archiwa III Rzeszy, ich losy i koncepcje powojennego wykorzystania, [w:] Niemcy jako problem międzynarodowy po II wojnie światowej, pod red. S. Sierpowskiego, Poznań 2010, s. 61-72.

${ }^{6} \mathrm{Z}$ treści sprawozdania wynika, że jego autor to przedwojenny pracownik instytucji bankowych. Według przechowywanej w zasobie Archiwum Państwowego w Poznaniu kartoteki mieszkańców Poznania (sygn. 15267), mógł to być Franciszek Wojciechowski, ur. 30 listopada 1899 r. i figurujący w tej kartotece jako „książkowy”. 
[Archiwum Państwowe w Poznaniu, Starostwo Powiatowe w Poznaniu, sygn. 498, s. 5-9. Pismo Franciszka Wojciechowskiego do starosty powiatu poznańskiego z 22 marca 1945 r.]

Komunalna Kasa Oszczędności Poznań, dnia 22. marca 1945 r. powiatu poznańskiego

Do Obywatela Starosty powiatu poznańskiego w Poznaniu.

Dotyczy: $\quad$ 1) Zabezpieczenie majątku b. niemieckiej Kasy Oszczędności (Kreissparkasse-Posen)

2) Wymiana marek niemieckich na złote polskie

3) Ustrój Komunalnej Kasy Oszczędności w Poznaniu

W związku z udzielonem mnie i obywatelowi RYBAKOWSKIEMU pełnomocnictwem składam niniejszym obywatelowi Staroście sprawozdanie z dotychczasowej czynności:

W Poznaniu, przy ul. 27-Grudnia $8 \mathrm{w}$ gmachu Komunalnego Banku Kredytowego mieściły się do dnia 20. stycznia b.r. lokale wyżej wymienionej Kasy Oszczędności (Kreissparkasse-Posen). Gmach ten w czasie okupacji niemieckiej nabył na skutek likwidacji Komunalnego Banku Kredytowego niemiecki Związek Elektryfikacyjny w Poznaniu, który w roku 1940 lokale parterowe $\mathrm{w}$ tymże gmachu położone wydzierżawił wspomnianej kasie. W skutek działań wojennych gmach ten stosunkowo bardzo mało został uszkodzony, zaś urządzenie biurowe tylko nieznacznie. Skarbiec, w którym znajdowało się 5 maszyn do pisania, 2 maszyny do liczenia i 3 maszyny do księgowania oraz urządzenie safesowe na około 300 schowków nie został uszkodzony. Ponieważ mnie wiadomem było, że duplikaty kluczy od skarbca złożone zostały do Landesbanku w Poznaniu, poczyniłem ja i ob. RYBAKOWSKI w tymże banku, którego skarbca zostały w międzyczasie przez wojska radzieckie gwałtem otworzone, poszukiwania, celem odnalezienia kluczy. Pomimo 2-dniowej pracy w podziemiach, nie mogliśmy kluczy odnaleźć. W międzyczasie i skarbiec b. Kreiasparkasse-Posen został dynamitem rozerwany. Przez siłę wybuchu zapadły się sufity nad skarbcem i zostały poważnie uszkodzone wszystkie maszyny oraz urządzenia safesowe, znajdujące się w skarbcu. Bardzo wątpię czy naprawa safesów będzie wogóle możliwa. Uszkodzone maszyny do pisania i liczenia zabraliśmy i znajdują się one w lokalu K.K.O, w gmachu Starostwa Powiatowego. Nie mogliśmy zabrać 3. cennych maszyn do księgowania, których przez wyłom w skarbcu nie można przedostać. Będzie to dopiero możliwym, jeżeli fachowiec od wewnątrz drzwi skarbca otworzy. Poza księgami kasowymi i kontami niem- 
ców znajdują się w skarbcu i ubikacjach przyległych do tegoż, materiały pisemne, które będzie jeszcze można użytkować. Zabezpieczenie tych materiałów ze względu na szczupły personel było dotychczas niemożliwe. Część urządzenia lokalu bankowego zostało przewiezione do lokalu K.K.O. w gmachu Starostwa Powiatowego. Ze względu na brak odpowiednich lokali trzeba było resztę urządzenia zostawić na miejscu. Użytkuje je na czas wymiany marek niemieckich Komunalny Bank Kredytowy, który będąc właścicielem gmachu przy ul. 27-Grudnia 8, lokale te obecnie zajmuje. Aby przygotować lokal dla K.K.O. w gmachu Starostwa dla celów wymiany, musieliśmy pracę z związane z uporządkowaniem skarbca i z zabezpieczeniem majątku przerwać. Jeżeli się wymiana zakończy to pracę tę się wznowi.

$\mathrm{W}$ powiecie poznańskim posiadała $\mathrm{b}$. Kreissparkasse Posen następujące oddziały i wpłatnie:

Oddziały:

1) w Swarzędzu

2) w Pobiedziskach

3) w Stęszewie

4) w Puszczykowie

5) w Tarnowie Podgórnym

6) w Biedrusku
Wpłatnie:

1) w Żabikowie

2) w Czerwonaku

3) w Dopiewie

Ze względu na brak środków komunikacyjnych, nie mieliśmy dotychczas możności przekonać się, czy lokale powyższych oddziałów są uszkodzonej i w jakim stanie znajduje się urządzenie biurowe tychże. Jedynie udaliśmy się pieszo do oddziału w Tarnowie Podgórnym, gdzie mieliśmy możność przekonać się, że urządzenia biurowego i książek kasowych już tam nie było. Odnośnie reszty oddziałów wystosowałem w dniu 6.b.m. za pośrednictwem ob. Starosty Powiatowego pisma do obywateli Burmistrzów i Wójtów wspomnianych wyżej miejscowości, celem zabezpieczenia lokali i ruchomości dla K.K.O. powiatu poznańskiego. Z relacji nadesłanych nam wynika, że część ruchomości zostało rozkradzione a reszta poważnie uszkodzona. Te ruchomości, które na miejscu się jeszcze znajdują, zostały zabezpieczone, a lokale dla K.K.O. zarezerwowane. Po wymianie marek niemieckich, jeżeli nastąpi normalna komunikacja kolejowa, będzie można dopiero się oddziałami kasy, a w szczególności zabezpieczeniem majątku tychże, zająć.

Komitet Ekonomiczny Rady Ministrów wezwał swego czasu kierowników i pracowników wszystkich po-niemieckich instytucji, znajdujących się na terenie miasta Poznania i Województwa Poznańskiego do zarejestrowania tychże. Ja obowiązek ten co do Kreissparkasse-Posen, spełniłem i udzielono mnie pełnomocnictwo do organizowania ochrony i zabezpieczenia majątku wspomnianej kasy pomimo, że wyraźnie zaznaczyłem, że kasa, jako instytucja prawno-publiczna, której, majątek jest cząstką majątku powiatu poznańskiego nie podlega z tych względów rejestracji. Również udzielono mnie 
pełnomocnictwa do zaangażowania kilka sił do prac związanych z zabezpieczeniem majątku kasy. $Z$ tego pełnomocnictwa skorzystałem i do tych prac na czas przejściowy zaangażowałem niżej wymienionych:

ob. Antoniego NOWAKA

ob. Marię KOPERSKĄ

ob. Janinę CZARNECKĄ.

Komunalny Bank Kredytowy i Komunalna Kasa Oszczędności miasta Poznania choć podzielają moje zdanie co do instytucji prawno-publicznych, zostały również w Komitecie Ekonomicznym Rady Ministrów zarejestrowane.

II. Wymiana marek niemieckich na złote polskie.

Przypuszczając, że K.KO. pow. poznańskiego będzie mogła nadal używać lokale po Kreissparkasse-Posen, zgłosiłem udział K.K.O. w akcji wymiany marek niemieckich. Nie wiedziałem wówczas, że Komunalny Bank Kredytowy będzie sobie rościł prawa do tego lokalu. Gdy to jednak się stało, miałem obawę, czy K.K.O. będąc teraz bez lokalu będzie mogła wogóle wymianę przeprowadzić. Dzięki przychylności ob. Starosty Powiatowego, który w gmachu Starostwa Powiatowego przydzielił K.K.O. narazie jeden większy pokój, można wymianę marek niemieckich choć w małych rozmiarach bo tylko dwoma kasami, przeprowadzić. Prace związane z tymi czynnościami są bardzo wyczerpujące dla szczupłego personelu kasowego. Jednak z drugiej strony przez wymiane zwraca K.K.O. na siebie uwagę mieszkańców miasta Poznania, że istnieje, przezco może później pozyskać klientów z miasta. Również zachodziła jeszcze obawa, czy K.K.O. nie mając skarbca do przechowania powierzonych pieniędzy, będzie mogła wogóle wymianę przeprowadzić. Te obawy zostały usunięte przez życzliwość kierownika zarządzającego K.K.O. miasta Poznania, który pozwolił naszej kasie przechowywać pieniądze w nieuszkodzonym swoim skarbcu, znajdującym się w Poznaniu, przy ul. Nowej, gdzie też i pieniądze tej kasy się przechowuje. Pieniądze przewozi się do skarbca powózką, stawiana do dyspozycji K.K.O. miasta Poznania przez Zarząd Miejski w asyście 5 pracowników wspomnianej kasy i 2 pracowników naszej kasy. Odbiór pieniędzy (złotych) ze skarbca następuje codziennie o godz. 6,45, a zamknięcie do skarbca o godz. 15,30. Wymienione marki niemieckie do czasu odstawienia do Narodowego Banku Polskiego pozostawia się w skarbcu i nie przewozi się ich codziennie do lokalu K.K.O. Komisarz dla spraw wymiany przydzielił naszej kasie narazie 1.500 .000 złotych na wymianę. Po 6.-dniach wymiany przy 2. wzgl. 3. kasach załatwiła nasza kasa 1.267 osób na ogólną sumę Rmk. 1.280.968.

\section{Ustrój Komunalnej Kasy powiatu poznańskiego}

Status Komunalnych Kas Oszczędności oparty jest na rozporządzeniu Prezydenta Rzeczypospolitej z dnia 13.4.1927 r. (Dz.Ust.R.P.Nr. 38 poz. 339) 
i z dnia 24.10.1927 r. (Dz.Ust.R.P.Nr: 95 poz. 360). Na podstawie wyżej wymienionych rozporządzeń i rozporządzenia Ministra Skarbu, Ministra Sprawiedliwości oraz Ministra Spraw Wewnętrznych z dnia 16.3.1937 r. (Dz.Ust. R.P.Nr:25 poz. 173) uzyskały Komunalne Kasy Oszczędności własną osobowość prawną. Statut Kasy uchwalony został przez Sejmik Powiatowy i zatwierdzony przez Komunalny Związek Kredytowy, który jest organem kontrolującym wszystkich kas oszczędności. K.K.O. powiatu poznańskiego założona została w roku 1906. Powiat poznański jako założyciel odpowiadał całym swoim majątkiem za zobowiązania kasy wobec osób trzecich.

Kapitał zakładowy K.K.O. pow. poznańskiego wynosił 150.000.-zł.

Na podstawie wspomnianego statutu organami kasy były:

1.) Rada Kasy, składająca się z każdorazowego Starosty powiatowego, jako Przewodniczącego i ośmiu (8) członków, wybranych spośród członków Sejmiku Powiatowego.

2.) Dyrekcja Kasy, składająca się i to:
a) Dyrektora zarządzającego,
b) zastępcy dyrektora zarządzającego
c) członka dyrekcji - niepłatnego.

Dyrektora zarządzającego i zastępcę dyrektora zarządzającego wybierała Rada Kasy. Wybór pierwszego i odwołanie musiał być zatwierdzony przez Ministra Skarbu. Wybór zastępcy dyrektora zarządzającego musiał być zaopiniowany przez Komunalny Związek Kredytowy.

3.) Komisja Rewizyjna składająca się z 3. członków wybieranych na okres 1. roku przez Sejmik Powiatowy.

Do obowiązków Rady Kasy należało

1.) uchwalenie preliminarza budżetowego kasy,

2.) uchwalenie regulaminów kredytowych i służbowych dla pracowników kasy,

3.) uchwalenie kredytów ponad 5.000.-zł.,

4.) zatwierdzenie bilansów i sprawozdań rocznych kasy.

5.) Wybór dyrektora zarządzającego i jego następcy,

6.) i t.p. sprawy.

Do obowiązków dyrekcji Kasy należało wykonanie wszystkich uchwał Rady Kasy, administrowanie majątku Kasy i uchwalenie kredytów do 5.000.-zł. Dyrektor zarządzający był przełożonym wszystkich pracowników kasy, zaś w razie jego nieobecności zastępca dyrektora zarządzającego.

Z chwilą wkroczenia wojsk niemieckich została zarządzona likwidacja wszystkich Komunalnych Kas Oszczędności, między innymi i K.K.O. powiatu poznańskiego. Niżej podpisany pracował do roku 1942 w Komunalnej Kasie Oszczędności pow. poznańskiego. W tym czasie zostały wszystkie książki, dokumenty i dowody przekazane głównemu likwidatorowi wszystkich polskich Kas Oszczędności. Jak zdołałem się dowiedzieć nie uległy dokumen- 
ty i książki naszej kasy wskutek działań wojennych, zniszczeniu. Pomiędzy innemi zachowały się tez akta organizacyjne wspomnianej kasy, w których znajduje się statut. Statut ten, będzie można zażądać po zakończeniu wymiany marek niemieckich, gdyż obecnie wszystkie siły pracujące w likwidacji zatrudnione są przy wymianie marek niemieckich.

W roku 1939 r. była K.K.O. pow. poznańskiego właścicielką następujących nieruchomości:

1.) terenu parcelacyjnego około 150 mórg, położonego w Szczepankowie (pow. poznański),

2.) placu budowlanego - $6250 \mathrm{~m}^{2}-\mathrm{w}$ Nowejwsi,

3.) placu budowlanego - $6250 \mathrm{~m}^{2}$ - w Poznaniu - Komandorja,

4.) gospodarstwa rolnego ca 24 mórg w Obrzycku.

Obecnie w K.K.O. pow. poznańskiego pracują z niżej podpisanym razem 10. pracowników i to:

1.) Franciszek WOJCIECHOWSKI - zastępca dyrektora zarządzającego,

2.) Maksymilian RYBAKOWSKI - pełnomocnik kasy,

3.) Marjan SCHNEIDER - urzędnik - księgowy,

4.) Gertruda BRZOSKÓWNA - maszynistka,

5.) Jerzy HETMAŃSKI - urzędnik bankowy,

6.) Bożena LUDKIEWICZ - siła biurowa,

7.) Maria KOPERSKA - siła biurowa,

8.) JANINA CZARNECKA - siła biurowa,

9.) Antoni NOWAK - woźny,

10.) Władysław MANIKOWSKI - kasjer tymczasowy.

Pracownicy ad 1-5) pracowali w K.K.O. już w roku 1939. Następnie zostali w czasie okupacji niemieckiej przejęci przez Kreissparkasse-Posen, która przejęła pracowniczkę ad 6). Do prac z związanych z zabezpieczeniem majątku Kreissparkasse-Posen, a specjalnie do prac z związanych z wymianą marek niemieckich przyjęto na czas przejściowy pracowników wymienionych ad 7-10).

W dniu dzisiejszym powrócił do Poznania dyrektor zarządzający Kasy ob. Stanisław MOHUCZY, którego miałem okazję ob. Staroście przedstawić.

Nie powróciło jeszcze 3. pracowników K.K.O., którzy swego czasu zostali ewakuowani przez władzę niemiecką do Generalgouvernement.

Do września 1939 r. mieściły się lokale K.K.O. pow. poznańskiego w gmachu Banku Przemysłowców w Poznaniu, Stary Rynek 73/74. Zalecałoby się przenieść K.K.O. do powyższych lokali z powodów następujących:

Lokal ten jest specjalnie urządzony na instytucję bankową i posiada 3 skarbce nieuszkodzone, co dla instytucji bankowej ma bardzo duże znaczenie. W skutek działań wojennych ucierpiał poważnie dach szklany tegoż lokalu i wyleciały wszystkie szyby z ulicy. Naprawa tych uszkodzeń i drobnej wewnętrznej przeróbki nie pociągnęła by za sobą poważnych kosztów. Choć 
na razie życie $w$ tej części miasta zamarło, to jednak spodziewać się należy, że niebawem rozpoczną się prace nad odbudową miasta a w szczególności dolnego miasta. Przez to ruch znacznie się wzmoży i kasa zyskać może klientów, wyprzedzając w tem K.K.O. miasta Poznania, która zamierza po naprawie poważnych uszkodzeń swego lokalu również przenieść się spowrotem do swoich lokali na ul. Nową. K.K.O. pow. poznańskiego nie powinna znajdować się w gmachu Starostwa Powiatowego, bo tam nie pozyska klientów. Nikt nie przyniesie swoich oszczędności do kasy, a specjalnie rolnicy z powiatu, aby nie ujawnić wobec władzy podatkowej swego majątku. Pracując już 18. lat w K.K.O. miałem możność się o tem przekonać. Nasza kasa będąc do roku $1930 \mathrm{w}$ gmachu Starostwa Powiatowego zawsze wykazywała do tego czasu straty bilansowe, dopiero z chwilą przeniesienia do śródmieścia, co nastąpiło na zarządzenie Komunalnego Związku Kredytowego pozyskała znacznie więcej klientów i ruch się wznowił, przezco i rentowność kasy się poprawiła.

Kierownik zarządzający

p.o.

(-) Fr. Wojciechowski

zastępca kierownika zarządz.

Krzysztof Stryjkowski

$$
\begin{aligned}
& \text { Wojenne i powojenne dzieje banków, } \\
& \text { ich skarbców i dokumentacji - } \\
& \text { przykład Komunalnej Kasy Oszczędności } \\
& \text { powiatu poznańskiego }
\end{aligned}
$$

\footnotetext{
Streszczenie

Dokumentacja bankowa jest dzisiaj przedmiotem wielostronnego zainteresowania. Najbardziej istotne było zawsze jej znaczenie praktyczne (dla banku oraz jego klientów). Z biegiem czasu stała się ona także przedmiotem studiów historyków, przede wszystkim gospodarczych. Okazuje się jednak, że materiały wytworzone przez banki i ich administracje posiadać mogą również wartość do innych badań. Badacze zainteresowani końcowym okresem II wojny światowej i walkami o Poznań odnajdą w prezentowanym dokumencie wiele informacji, które rzucą nowe światło na sytuację w mieście oraz pozwolą wczuć się w klimat tamtych dni. Dokument ukazuje ponadto problemy związane z odbudową systemu bankowego oraz wprowadzaniem w stolicy Wielkopolski nowego środka płatniczego - złotego polskiego, który zastąpił obowiązującą dotychczas markę niemiecką.
} 


\title{
War and post-war history of banks, their vaults and records as exemplified by the Communal Savings Bank of the Poznań county
}

\begin{abstract}
At present, banking documentation is a subject of interest for many parties. The practical value of this documentation has always been of prime importance, both for the bank and for its clients. With time, it also became a subject of interest for historians, particularly those specialized in economy. It turns out, though, that materials created by banks and their administrative bodies can also be of value for other researchers. Researchers interested in the final period of the Second World War and battles for Poznań will find this document informative, as it not only sheds new light on the situation in the city, but will also enable them to feel the atmosphere of those days. The document also shows the problems related to reconstructing the banking system and introducing the new currency, the Polish złoty (which replaced the German mark used until that point), in the capital of Greater Poland.
\end{abstract}

